\title{
Determinants of Bank Profitability in Nigeria
}

\author{
Eze Simpson Osuagwu ${ }^{1}$ \\ ${ }^{1}$ Department of Economics, University of Lagos, Nigeria \\ Correspondence: Eze Simpson Osuagwu, Department of Economics, University of Lagos, Nigeria. Tel: \\ 234-803-321-4346. E-mail: ezesosuagwu@gmail.com
}

Received: Septmber 15, 2014

Accepted: September 26, 2014

Online Published: November 25, 2014

doi:10.5539/ijef.v6n12p46

URL: http://dx.doi.org/10.5539/ijef.v6n12p46

\begin{abstract}
There are increasing scholarly debates on the direction of policy to effectively improve the performance of banks. Some scholars argue that bank performance is enhanced by improvements in the internal organization and managerial efficiency others argue that industry wide factors are integral to bank performance. In recent times, the direction of literature has shown that macroeconomic factors play a significant role in determining bank profitability. This paper investigates the determinants of bank profitability in the light of bank specific variables, industry related factors and macroeconomic influences, using a panel of selected banks that account for over $60 \%$ of total bank assets in Nigeria. Findings show that bank profitability is largely determined by credit risk and other factors that relate to the internal organization of banking firms. Market concentration is significant as a determinant of bank profitability. There is no evidence of structure-conduct-performance hypothesis, however empirical results show that there is no collusive behavior amongst banks. Exchange rate is significant as a determinant of bank profitability through return on equity and non-interest margin, but not significant to return on asset as a measure of profitability.
\end{abstract}

Keywords: bank profitability, concentration, market structure, panel data

\section{Introduction}

Bank profitability is an important ingredient of financial development, its relevance spans through banking firm performance to macroeconomic stability. At the firm level, a higher return to a large extent reduces bank fragility. At the macro level, increased profitability makes for a sustainable banking sector that can finance economic growth and development. However, due to the intermediation role of the banking system, higher returns may imply higher interest rates on loans. This informs a reason why monetary authorities are always poised to regulating the banking system. Increased regulations and counter deregulations have encouraged competition in the banking sector, and hence exposed banks to increased fragility. For example between 1990 and 2004, bank regulators have increased the minimum share capital of banks operating in Nigeria five times (Aburime \& Uche, 2008). These reforms were all aimed at improving the balance sheet, profitability and stability of banks in Nigeria, even though the outcomes sometime differ from expectations.

Policy makers have often resorted to increasing the minimum share capital to fix an imminent shortfall in bank balance sheet, with the conviction that bank fragility is often allayed by a strong capital base. This assertion has been supported by evidence; whether there is a correlation between equity and profit margin has been widely discussed in the literature (see Berger, 1995a). Unfortunately, many country level studies have relied more on bank-specific determinants, while ignoring the influence of macroeconomic factors on bank profitability. If bank profits are re-invested, it becomes a major source of equity capital and therefore promotes stability. On the other hand, weak economic performance promotes the deterioration of credit quality, and increases the probability of loan default (Flamini et al., 2009). There have been increasing scholarly debates on the direction of policy to effectively ensure the performance of the banking sector. Whilst some scholars have argued that bank profitability is enhanced by the improvements in the internal organization and managerial efficiency of the bank itself, others argue that industry wide factors are integral to the profitability of banks. In recent times, the direction of literature has shown that macroeconomic factors also play significant role in determining bank profitability. In this paper the ultimate goal is to explore the determinants of bank profitability in a developing economy such as Nigeria: whether bank profitability is determined by bank specific variables, industry related factors and/or macroeconomic variables. 
The motivation for this study stem from the dearth or lack thereof of country specific studies that have examined the significance of both bank specific, industry related and macroeconomic variables as determinants of bank profits in Nigeria. Existing known studies in this direction are in two categories: those that have focused on a particular country (e.g. Berger et al., 1987; Berger, 1995b; Barajas et al., 1999; Naceur \& Goaied, 2001; Naceur, 2003; Athanasoglou et al., 2006) and those that have focused on a panel of countries (Bourke, 1989; Molyneux \& Thornton, 1992; Demirgüç-Kunt \& Huizinga, 1999, 2001; Abreu \& Mendes, 2002; Flamini et al., 2009).

This study will focus on the analysis of the significance of bank specific variables as well as industry related and macroeconomic factors as determinants of bank profitability in Nigeria using bank level data for the period 1980-2010. The findings of this study will extend the existing body of literature in this subject matter. It will also enable policy makers to understand the variables to target in the formulation of policies that will enhance the performance of banks, which hitherto will promote stability in the banking system.

This study is presented in six sections. A brief overview of the Nigerian banking sector is discussed in the second section. The third section is a review of selected related literature, the fourth section discusses the data and the model specification, the fifth section is on the empirical analysis and the results, while the sixth section concludes the study.

\section{The Nigerian Banking Sector: An Overview}

Indigenous banking in Nigeria dates back to the British West Africa and the establishment of Bank of British West Africa (BBWA) in 1894. By 1969 BBWA took out Nigerian incorporation to become Standard Bank Nigeria Ltd. Meanwhile in 1972 under the first Nigerian Enterprises Promotion Decree (1972), banks were required to put at least $40 \%$ of their shares in the hands of Nigerian citizens. The Government acquired $36.1 \%$, the Nigerian Public $12.9 \%$ leaving $51 \%$ in the hands of expatriate shareholders. In 1972, there were only 367 bank branches operated by sixteen banks. By 1975, the number of bank branches had risen to 436 and by 1978 to 585, with eighteen banks firmly in operation. As at December 1977 there were 18 commercial banks (including the cooperative banks) operating in Nigeria. Until 1977, two broad classifications could be applied to commercial banks depending on whether Nigerians hold a majority or minority interest in the institution.

In 1986 the federal government embarked on a Structural Adjustment Program (SAP), which liberalized the licensing of banks and deregulated interest rates on deposit and lending. The policy of liberalization transformed the banking system and introduced competition. As a result in 1990 the number of banks increased from 29 in 1986 to 58 banks operating 1,169 urban, 765 rural and 5 foreign branch offices.

In 2001, the Central Bank of Nigeria (CBN) introduced universal banking, thereby removing the operational distinction between commercial and merchant banks. The implication of this is that both commercial and merchant banks are referred to as Deposit Money Banks (DMBs) and they are to operate on a level playing field. At the end of 2002, major macroeconomic targets set in; the medium term monetary policy framework indicated that aggregate bank credit grew by $56.6 \%$ as against the target growth rate of $57.9 \%$. Credit to the Federal Government also grew astronomically from $96.6 \%$ to $6,320.6 \%$ at the end of 2002 . In addition inflation rate overshot the target of $9.3 \%$ to settle at $12.9 \%$, while a $3.3 \%$ growth rate was achieved in respect of the Gross Domestic Product (GDP) as against the policy target of 5.0\%. The broad measure of money supply $\left(\mathrm{M}_{2}\right)$ rose by $21.5 \%$ compared with the $15.3 \%$ targeted, while narrow money stock $\left(\mathrm{M}_{1}\right)$ increased by $15.9 \%$ as against the $12.4 \%$ performance target for the year. The growth in broad money was induced by the sharp growth in credit to the Federal Government during the period.

In furtherance of CBN's statutory responsibility of ensuring a safe and sound financial system, the contingency plan for banking system distress resolutions, which was developed jointly with the Nigerian Deposit Insurance Corporation, became effective in July 2002. Also the Central Bank initiated a private sector funded "lifeline" facility that was accessed by banks with temporary liquidity problems. These, in addition to the Financial Sector Assessment Program (FSAP) conducted jointly by the IMF and the World Bank to assess the soundness of Nigeria's financial sector, based on international standards, were aimed at strengthening the financial system.

Another major reform aimed at improving bank performance was introduced in July 2004 as part of a home grown economic development agenda of the civil administration. One of the secondary objectives of the National Economic Empowerment and Development Strategy (NEEDS) was to strengthen the financial system. In order to do this the Central Bank announced an increase in the minimum capital of banks from 2 billion to 25 billion Naira, with a deadline of December 31, 2005 for full compliance. The announcement of the reform with the attendant increase of the minimum capital requirement sent shockwaves through the banking industry. The idea of consolidation was quickly embraced by the banking community and the process of mergers and acquisition ensued. One of the major reasons given by the Central Bank was that many Nigerian banks cannot provide the necessary 
financing needed to grow the economy. Most had a capital base of less than US\$10 million, and several had bad balance sheets. The banking sector was highly concentrated with the ten largest accounting for about half the industry 's total assets and liabilities, the remaining 79 banks were small but had heavy fixed and operating costs, resulting in very high average cost for the industry (Okonjo-Iweala, 2012). The attempts to cover these costs led to wide spreads between deposit and lending rates and to a focus on lucrative short-term arbitrage of foreign-exchange "round-tripping" rather than on lending to the real sectors.

The number of banks reduced from 89 in 2004 to 25 as at January 2006 through mergers and acquisitions and their minimum capital requirement raised from 2 billion Naira to 25 billion Naira or more. In a bid to meet this minimum capital banks raised an equivalent of US\$3 billion from the capital market through initial public offerings (IPO) and attracted over US\$652 million in foreign direct investment (Okonjo-Iweala, 2012). The Nigerian banking industry witnessed an explosive growth following consolidation, between June 2006 and June 2008 , the number of bank branches grew by 54 percent, the number of deposit accounts by 39 percent, total loans and advances by 197 percent, bank credit to the private sector grew by 60 percent in 2007 and another 90 percent in 2008. Credit to the private sector was able to finance large infrastructure projects and oil and gas projects. Some Nigerian banks became key players in the international market by opening branches in other West African countries and in major European capitals.

\section{Literature Review and Theoretical Framework}

The measures of bank profitability usually considered in the literature on the determinants of bank profitability are the return on assets (ROA), return on equity (ROE) and in some cases, the net interest margin (NIM). Bank profitability determinants are usually explained in the form of internal and external variables. The internal variables are those that determine bank's management decisions and specifically affect policy objectives, such as liquidity risk, credit risk, bank size, financial leverage and expense management. The external variables are those that emanate from industry related factors and macroeconomic influences, which includes competition and the level of concentration, the level of unemployment, inflation rate and real per capita income. In the case of Nigeria, exchange rate may pose a macroeconomic influence on bank profitability because of the variation in the exchange rate of the domestic currency to the US dollar and other major currencies.

Studies on the determinants of bank profitability and/or performance have been broadly distinguished into two categories; those that are based on country specific data and those that used a panel of countries. The studies by Molyneux and Thornton (1992), Demirguc-Kunt and Huizinga (1999, 2001), Abreu and Mendes (2002), Goddard et al. (2004), Beck et al. (2005), Athanasoglou et al. (2006), Micco et al. (2007), Pasiouras and Kosmidou (2007), and Flamini et al. (2009) investigate a panel data set of countries. Studies by Berger et al. (1987), Berger (1995), Neely and Wheelock (1997), Naceur (2003), Mamatzakis and Remoundos (2003), Naceur and Goaeid (2001), and Athanasoglou et al. (2008) focus their analyses on single countries. Although, results of the empirical analysis of these studies differ based on the specification of the model and the nature of the explanatory variables employed, there still exist reasons to show the significance of bank specific factors, industry related effects and macroeconomic or environmental influence.

Empirical evidence by Bourke (1989), Demirguc-Kunt and Huizinga (1999), Abreu and Mendes (2002), Goddard et al. (2004), Naceur and Goaied (2001), and Pasiouras and Kosmidou (2007) indicate that banks that hold a high level of equity relative to their assets perform better in terms of profitability. These studies suggest that as bank's capital ratios increase, the cost of funding tend to fall due to lower prospective bankruptcy costs. Furthermore, overhead costs are also an important determinant of profitability: the higher the overhead costs in relation to the assets, the lower the profitability of a bank (Athanasoglou et al., 2008).

Molyneux and Thornton (1992) in the study on the determinants of bank profitability use a sample of 18 European countries during the period 1986-1989. They find a significant positive association between the return on equity and the level of interest rates in each country, bank concentration and government ownership. Abreu and Mendes (2002) investigate the determinants of banks' interest margins and profitability for some European countries noting that well capitalized-banks face lower expected bankruptcy costs and this advantage "translate" into better profitability. The macroeconomic variables employed in the study; unemployment rate show a negative but significant relationship, while inflation rate is observed to be a relevant factor in explaining bank profitability.

Goddard et al. (2004) study the performance of European banks across six countries. They find a relatively weak relationship between size and profitability-measured by return on equity. Only banks in the United Kingdom show a significantly positive relationship between off-balance-sheet business and profitability. Even though competition among banks is thought to have increased over the period, there is significant persistence of 
cumulative abnormal profit for the period, 1992-1998.

Naceur and Goaied (2001) study the performance of Tunisian deposit banks (1980-1995), and observe that productivity change, market capitalization, and bank portfolio composition are significant and positively related to return on assets, but not the size of the bank. In the same vein, using co-integration techniques, Chirwa (2003) studied eight banks in Malawi (1970-1984) and finds a significantly positive long run relationship between concentration and performance; similarly for demand deposits.

Pasiouras and Kosmidou (2007) find a positive and significant relationship between size and profitability of a bank. Other authors, such as Berger et al. (1987), provide evidence that costs can be reduced only slightly by increasing the size of a bank and that very large banks often encounter scale inefficiencies. Micco et al. (2007) find no correlation between the relative bank size and the return on assets for banks, i.e., the coefficient is always positive but never statistically significant. A major determinant of bank profitability is the credit risk or liquidity risk the bank is willing to undertake. Abreu and Mendes (2002), who examined banks in Portugal, Spain, France and Germany, find that the loans-to-assets ratio, as a proxy for risk, has a positive impact on the profitability of a bank. Bourke (1989) and Molyneux and Thornton (1992), among others, find a negative and significant relationship between the level of risk and profitability. This result might reflect the fact that financial institutions that are exposed to high-risk loans also have a higher accumulation of unpaid loans. These loan losses lower the returns of the affected banks.

Furthermore, Beck et al. (2005) in assessing the effect of privatization on the performance of Nigerian banks from 1990-2001, controlled for the age of the bank, since longer established banks might enjoy performance advantages over relative newcomers. Their results for the Nigerian market indicate that older banks did not perform as well as newer banks, which were better able to pursue new profit opportunities.

Athanasoglou et al. (2008) include external determinants of bank profitability such as central bank interest rate, inflation, the GDP development, taxation, or variables representing market characteristics (e.g., market concentration). The results indicate that industry structure does not affect profitability of Greek banks between 1985 and 2001, but macroeconomic determinants and bank specific variables were significant. Most studies have shown a positive relationship between inflation, central bank interest rates, GDP growth, and bank profitability (e.g., Bourke, 1989; Molyneux \& Thornton, 1992; Demirguc-Kunt \& Huizinga, 1999).

Nevertheless, there is some evidence that the legal and institutional characteristics of a country matter. The study of Demirguc-Kunt and Huizinga (1999) reports that taxation reduces bank profitability. Another study by Albertazzi and Gambacorta (2006) concludes that the impact of taxation on banking profitability is small because banks can shift a large fraction of their tax burden onto depositors, borrowers, or purchasers of fee-generating services. Overall, although fiscal issues are likely to exert a significant influence on the behavior of a bank, the taxation of the financial sector has received little attention.

To measure the effects of market structure or industry related effects on bank profitability, the structure-conduct performance (market-power) hypothesis states that increased market power yields monopoly profits. According to the results of Bourke (1989) and Molyneux and Thornton (1992), the bank concentration ratio shows a positive and statistically significant relationship with the profitability of a bank and is, therefore, consistent with the traditional structure-conduct-performance paradigm. In contrast, the results of Demirguc-Kunt and Huizinga (1999) and Staikouras and Wood (2004) indicate a negative but statistically insignificant relationship between bank concentration and bank profits. Likewise, the estimations by Berger (1995) and Mamatzakis and Remoundos (2003) contradict the structure-conduct performance hypothesis.

Flamini et al. (2009) in studying the determinants of commercial bank profitability in sub-Saharan Africa explored the impact on bank performance of bank-specific factors, such as risk, market power, and regulatory costs in addition the research has focused on the impact of macroeconomic factors on bank performance.

Using accounting decompositions, as well as panel regressions, Al-Haschimi (2007) studies the determinants of bank net interest rate margins in 10 SSA countries. He finds that credit risk and operating inefficiencies (which signal market power) explain most of the variation in net interest margins across the region. Macroeconomic risk has only limited effects on net interest margins in the study.

Saunders and Schumacher (2000) apply the model of Ho and Saunders (1981) to analyze the determinants of interest margins in six countries of the European Union and the US during the period 1988-1995. They find that macroeconomic volatility and regulations have a significant impact on bank interest rate margins. Their empirical evidence supports an important trade-off between ensuring bank solvency, as defined by high capital to asset ratios, and lowering the cost of financial services to consumers, as measured by low interest rate margins. 
Saunders and Allen (2004) survey the literature on pro-cyclicality in operational, credit, and market risk exposures. Such cyclical effects mainly result from systematic risk emanating from common macroeconomic influences or from interdependencies across firms as financial markets and institutions consolidate internationally. They may ultimately exacerbate business cycle fluctuations due to adverse effects on bank lending capacity.

Athanasoglou et al. (2006) in their study of the profitability behavior of the South Eastern European banking industry over the period 1998-2002 observed that the enhancement of bank profitability in those countries requires new standards in risk management and operating efficiency, which, according to the evidence presented in the paper, crucially affect profits. A key result is that the effect of market concentration is positive, while the picture regarding macroeconomic variables is mixed.

The theoretical framework for this study follows market power models established under the new empirical industrial economics literature for the analysis of competition and profitability in the banking sector. The structure conduct performance (SCP) paradigm stipulates that as market concentration is increasing bank profitability should be decreasing if there is no collusive behavior amongst firms in the industry. However, if bank profit is increasing as concentration is increasing the implication is that firms in the industry are colluding to reap oligopoly profits. Another variant of market power model is the efficient-structure (EFS) hypothesis, which stipulates that higher market concentration may result when efficient firms generate high profits as a result of an increase in size and market share. In this case, market concentration in an industry is not a random occurrence but a product of superior efficiency possessed by some firms. Both SCP and EFS have been tested in Bourke (1989) and Molyneux (1993) for the Belgium, French, Italian, Dutch and Spanish banking markets.

Berger (1995), Goldberg and Rai (1996) have examined the implications of the EFS hypothesis on market structure for the United States and European banking market respectively. Flamini et al. (2009) finds no direct effect of market concentration on bank profitability for sub-Saharan Africa banking markets due to the limitations of the proxy for concentration imposed on the profitability of banks in the region. This study did not use the traditional Hirschman-Herfindahl Index (HHI) or three-firm concentration ratio because of incomplete information arising from data inconsistency. However, the study tested the existence of market power using the ratio of each bank's total outstanding loans to the net domestic credit of the country as a measure of market concentration. The empirical derivation for the structure-conduct-performance (SCP) and efficient-structure (EFS) hypotheses is shown in Bicker and Bos (2008).

\section{Data and Model Specification}

\subsection{Data}

The data for this study is obtained from the annual balance sheet of sampled banks for the estimation of bank specific and industry related variables. The data for macroeconomic variables is obtained from the statistical bulletin and annual reports of Central Bank of Nigeria (CBN) for various years. The dataset includes a panel of selected banks which hold about $60 \%$ of the industry's total assets. We assume that the financial year of all banks in our sample is twelve calendar months and run from January to December. Our study period is from 1980 to 2010, but unbalanced panel because a few data points could not be filled due to lack of available data for the period.

\subsection{Model Specification}

To estimate the relationship between bank profitability and bank specific, industry related and macroeconomic variables, we apply a linear regression model with logarithmic transformation where applicable as stated in Athanasoglou et al. (2006), Chirwa and Mlachila (2004), Brissimis et al. (2008)

$$
\begin{aligned}
\prod_{i t}=c+\Sigma \beta_{j} X_{i t}^{j} & +\Sigma \beta_{k} X_{i t}^{k}+\Sigma \beta_{l} X_{i t}^{l}+\varepsilon_{i t} \\
\varepsilon_{i t} & =v_{i}+\mu_{i t}
\end{aligned}
$$

where $\prod_{\mathrm{it}}$ is the profit function of bank $i$ at time $t$, with $i=1, \ldots, \mathrm{N} ; t=1, \ldots, T$; c is a constant term, the $X$ 's are explanatory variables (grouped into bank-specific, industry-related and macroeconomic determinants, $j, k$ and $l$ respectively) and $\varepsilon_{i t}$ is the stochastic element, with $\boldsymbol{v}_{\boldsymbol{i}}$ capturing the unobserved heterogeneity of bank-specific effect and $\mu_{i t}$ the idiosyncratic error. This econometric model follows a one way error component regression model, where $\boldsymbol{v}_{\boldsymbol{i}} \sim \operatorname{IIN}\left(0, \sigma^{2}{ }_{v}\right)$ and independent of $\boldsymbol{\mu}_{\boldsymbol{i t}} \sim \operatorname{IIN}\left(0, \sigma^{2}{ }_{v}\right)$.

\subsection{Dependent Variables}

The most common measures of profitability $\left(\prod_{i}\right)$ employed are net income to equity or return on equity (ROE), net income to total assets or return on assets (ROA) and net interest margin (NIM). The profitability of a bank has been 
measured by Return on Assets and Return on Equity in Athanasoglou et al. (2006), Egesa (2010), Flamini et al. (2009), Xiaoqing (Maggie) Fu and Hefferman (2009). Net Interest Margin (NIM) has been applied in Brissimis et al. (2008), which represents the interest earned on a bank's portfolio exceeds the interest paid on deposits or borrowed funds. Net Interest Income is a traditional measure of intermediation spread, which is the difference between bank's interest income and interest expense. Studies that examine the determinants of NIM include Saunders and Schumacher (2000) and Maudos and de Guevara (2004). A potential weakness of NIM may be that, as banks move toward more fee-generating activities, NIM will decline in importance as a measure of profitability.

\subsection{Explanatory Variables}

\subsubsection{Bank Specific Variables}

Opportunity Cost of holding reserves with Central Bank (OPP) - Saunders and Schumacher (2000) argue that the existence of non-interest bearing reserve requirements increases the economic cost of funds over and above the published interest expenses. Ho and Saunders (1981) and Saunders and Schumacher (2000) define this as the ratio of non - interest bearing reserve assets to the total interest earning assets multiplied by the average Treasury bill rate. In this study, the ratio of non-interest-earning assets to total assets multiplied by the Treasury bill rate is used as a proxy for the opportunity cost of holding reserves (OPP), which is expected to be positive and significant to profitability.

The ratio of operating expense to total assets (OEA) - This is the proxy for the average cost of non-financial inputs to banks (Fries \& Taci, 2005). Operating expenses consist of staff expenses, which comprise salaries and other employee benefits (including transfers to pension reserves and administrative expenses). Administrative expenses include various types of bank expenses associated with bank operations, such as the adoption of new information technology, depreciation, legal fees, marketing expenses, or non-recurring costs related to bank restructuring. Provision for loan losses was not included in operating expenses. Athanasoglou et al. (2006) find a negative but significant effect of operating expenses on profitability of South Eastern European banks.

The ratio of total loans to total assets (TLA) - This ratio measures credit risk, which reflect changes in the health of a bank's loan portfolio (see Cooper et al., 2003), which may affect the performance of the institution. Duca and McLaughlin (1990), among others conclude that variations in bank profitability are largely attributable to variations in credit risk, since increased exposure to credit risk is normally associated with decreased firm profitability.

The ratio of total deposit to total loans (DTL) as a measure of bank's credit risk has shown a positive relationship to bank profitability (Flamini et al., 2009). Given that the portfolio of outstanding loans is non-tradable, credit risk is modeled as a predetermined variable in their specification (Flamini et al., 2009). Based on standard asset pricing arguments, we expect a positive association between profits and bank risk. Al-Haschimi (2007) finds a positive effect of credit risk on Sub-Saharan African net interest margins.

The ratio of non-interest income to operating profit (NOP) - The coefficient of NOP could be positive or negative depending on the bank's expertise or strategic objective. We could expect it to be positive if a bank has the technical ability to offer non- interest income product lines, i.e., fee based services, which permit the bank to achieve a higher level of efficiency from its resources (especially its human capital). We would expect it to be negative if the bank human capital resources and expertise is oriented more towards traditional commercial and industrial lending activities. Zhao and Murinde (2011) find that the ratio of non-interest income to operating profit is significant in determining bank profits.

Ratio of Demand Deposits to Total Deposits (DTD) - Is included to capture the impact of deposit mix on profitability. Having a higher proportion of demand deposits increases the level of efficiency because banks can utilize this source of financial capital (core deposits) without incurring higher interest cost (see Chen, 2009). The ratio of demand deposit to total deposit (DTD) is a measure of liquidity in the banking system.

The ratio of non-performing loans to total loans (NPL) is a measure of the strength of environmental variables on bank performance. A high ratio of non-performing loans reduces the revenue and profit accruing to a bank. This ratio also measures credit risk (Kumbakhar et al., 2001, Zhao \& Murinde, 2011).

\subsubsection{Industry-Related Factors}

The most important step in assessing banking market power is the choice of a measure for concentration and competition. Claessens and Laeven (2004) argue that performance measures such as banks' net interest margin or profitability do not appropriately indicate the competitiveness of a banking industry. These measures can be influenced by a number of factors such as firm specific performance and stability, the form and the degree of financial intermediation, the quality of institutions, and bank-specific factors. Beck (2008) also highlights that 
traditional indicators of competition based on market structure and concentration measures, such as the Hirschman-Herfindahl index (HHI), as well as concentration ratios, which are rather crude measures that do not take differentiation strategies into consideration. Hence, Soedarmono (2010) observe that such indicators only capture the actual market share without allowing inferences on the competitive behavior of banks. The HHI has been widely used in studies to capture the effect of competition and market concentration on banks performance (Xiaoquing (Maggie) Fu \& Hefferman, 2009). For this study the HHI will be used as a measure of bank concentration.

\subsubsection{Macroeconomic Determinants}

Exchange Rate (EXR) - This variable measures the impact of environmental conditions on the banking system. The result may vary depending on whether a fixed or flexible exchange rate regime is adopted. However, as observed in Domac and Martinez-Peria (2003), adopting a fixed exchange rate diminishes the likelihood of a banking crisis in developing countries, hence profit is maximized. On the other hand, Arteta and Eichengreen (2002) earlier observed that countries with fixed and flexible exchange rates are equally prone to banking crisis, which implies low levels of profitability.

Inflation Rate (INF) has been widely used as proxy for the effect of macroeconomic environment on bank performance (Athanasoglou et al., 2006; Chen 2009; Flamini et al,. 2009). The relationship between the inflation rate and profitability is somewhat ambiguous and often depends on whether or not inflation is anticipated. Bourke (1989), Molyneux and Thornton (1992), found a positive relationship between inflation and bank performance. Whether inflation affects profitability depends on whether wages and other non-interest costs are growing faster than the rate of inflation. Demurgic Kunt and Huizinga (1999) also found positive relationship between inflation and Net interest margin.

\section{Empirical Analysis and Results}

\subsection{Empirical Analysis}

First, a test for the presence of multicollinearity using the correlation coefficient of the variables to ascertain which of the variables will be relevant for the analysis of our model. Second, the relevant variables will be fitted in the model of a panel analytic study for the fixed and random effects estimation and several diagnostic tests will be conducted with a view to obtaining the most plausible measures of profitability as our estimation technique permits.

Table 1. Correlation matrix

\begin{tabular}{|c|c|c|c|c|c|c|c|c|c|c|c|c|c|}
\hline & Iroa & Iroe & Inim & OPP & DTD & NPL & NOP & OEA & TLA & DTL & Ihhi & lexr & $\operatorname{linf}$ \\
\hline & $\mathrm{b}$ & b & $\mathrm{b}$ & $\mathrm{b}$ & b & $\mathrm{b}$ & $\mathrm{b}$ & $\mathrm{b}$ & $\mathrm{b}$ & $b$ & $\mathrm{~b}$ & $\mathrm{~b}$ & $\mathrm{~b}$ \\
\hline Iroa & 1 & & & & & & & & & & & & \\
\hline Iroe & 0.667938 & 1 & & & & & & & & & & & \\
\hline Inim & 0.343049 & 0.13617 & 1 & & & & & & & & & & \\
\hline OPP & -0.05296 & 0.024876 & 0.299294 & 1 & & & & & & & & & \\
\hline DTD & 0.143834 & 0.002782 & 0.210822 & -0.05465 & 1 & & & & & & & & \\
\hline NPL & -0.07428 & 0.0207 & 0.437699 & 0.546191 & -0.02816 & 1 & & & & & & & \\
\hline NOP & 0.10846 & 0.073231 & 0.101614 & 0.062911 & -0.04388 & 0.065971 & 1 & & & & & & \\
\hline OEA & 0.277613 & 0.132587 & 0.766724 & 0.317084 & 0.335114 & 0.439206 & 0.054301 & 1 & & & & & \\
\hline TLA & -0.14286 & -0.08466 & -0.21579 & -0.25537 & -0.14328 & -0.4034 & -0.0113 & -0.34006 & 1 & & & & \\
\hline DTL & -0.09105 & -0.01477 & -0.00989 & 0.086717 & -0.03601 & 0.311913 & 0.005174 & 0.07292 & -0.7391 & 1 & & & \\
\hline Ihhi & -0.13762 & -0.28584 & -0.1463 & -0.27039 & 0.195303 & -0.24631 & 0.019706 & -0.17821 & 0.25148 & -0.15107 & 1 & & \\
\hline lexr & 0.28688 & -0.09461 & 0.49398 & 0.070157 & 0.325592 & 0.257032 & 0.050909 & 0.574601 & -0.55834 & 0.330214 & 0.051779 & 1 & \\
\hline $\operatorname{linf}$ & 0.022914 & 0.107613 & 0.059819 & 0.404843 & -0.06546 & 0.343508 & 0.082728 & 0.123832 & -0.14213 & 0.040536 & -0.15738 & -0.0724 & 1 \\
\hline$N$ & 141 & & & & & & & & & & & & \\
\hline
\end{tabular}

Note. Data is normalized by taking the log of all dependent varibles, market concentration variable and macroeconomic variables.

Source: Bank annual report and central bank of Nigeria statistical bulletin for various years.

Table 1 presents the result of multicolinearity test for all the variables used in the analysis. Variables with correlation coefficients of about 0.2 absolute basis points away from 1 or -1 may be considered multicollinear. However, in the process of estimating Panel fixed effects model Stata is able to detect multicollinear variables and drop same from the regression appropriately, while other diagnostic tests have been applied to the estimation for stylized and robust estimation results. 
The econometric analysis for this study is couched in three models based on the dependent variables. In the first model, the dependent variable is the return on assets, second is the return on equity and third is the net interest margin. In other to normalize the dependent variables, the log values are used in the estimation. Similarly, log values of market concentration variable (Hirschman-Herfindahl index) and all the macroeconomic variables have been used in the estimation.

Table 2 provides the descriptive statistics of the variables used in this analysis. The minimum value of 0 indicates that no data point is available for the given observation hence our panel data is unbalanced. In column 2 , the number of observations corresponds to the number of data points available for a variable. Aside from NOP which has a very wide data range with a standard deviation of 21.4 every other variable in the estimation falls within statistically acceptable range of values; in terms of the mean, standard deviation, minimum and maximum data points.

Table 2. Descriptive statistics

\begin{tabular}{llllll}
\hline Variable & Obs & Mean & Std. Dev. & Min & Max \\
\hline lroa & 141 & -4.393264 & 0.7763751 & -7.528869 & -2.880163 \\
lroe & 141 & -1.694198 & 0.9104956 & -5.517494 & 2.890372 \\
lnim & 150 & -2.970046 & 0.4972508 & -4.820282 & -1.674743 \\
OPP & 155 & 1.63962 & 1.224146 & 0 & 7.761322 \\
DTD & 155 & 0.4340951 & 0.2117458 & 0 & 1.318395 \\
NPL & 155 & 0.2149832 & 0.1639178 & 0 & 0.8842832 \\
NOP & 155 & -1.254065 & 21.41071 & -200 & 132 \\
OEA & 155 & 0.0543181 & 0.0293081 & 0 & 0.1576946 \\
TLA & 155 & 0.3639869 & 0.1449657 & 0 & 1.07085 \\
DTL & 155 & 2.151691 & 0.8620459 & 0 & 7.065759 \\
lhhi & 155 & 7.906703 & 0.0747621 & 7.808729 & 8.12415 \\
lexr & 155 & 2.808651 & 1.971538 & -0.604404 & 5.027164 \\
linf & 155 & 2.689888 & 0.7800743 & 1.686399 & 4.287716 \\
\hline
\end{tabular}

Figures 1, 2 and 3 below show histogram of the distribution of return on assets, return on equity and net interest margin respectively. In order to achieve symmetry, data for the variables has been transformed to logarithmic scale. As can be seen from the histogram despite all the constraints of data availability a considerable level of symmetric distribution of the dependent variables has been achieved using the log transformation.

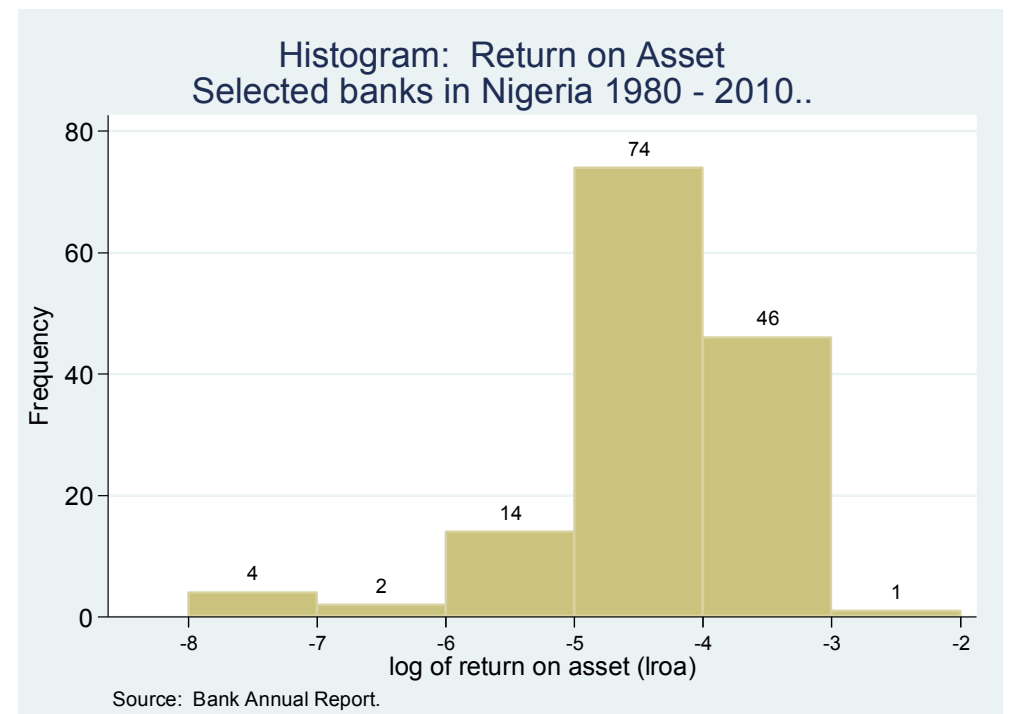

Figure 1. The distribution of return on assets for selected banks in Nigeria 1980-2010 


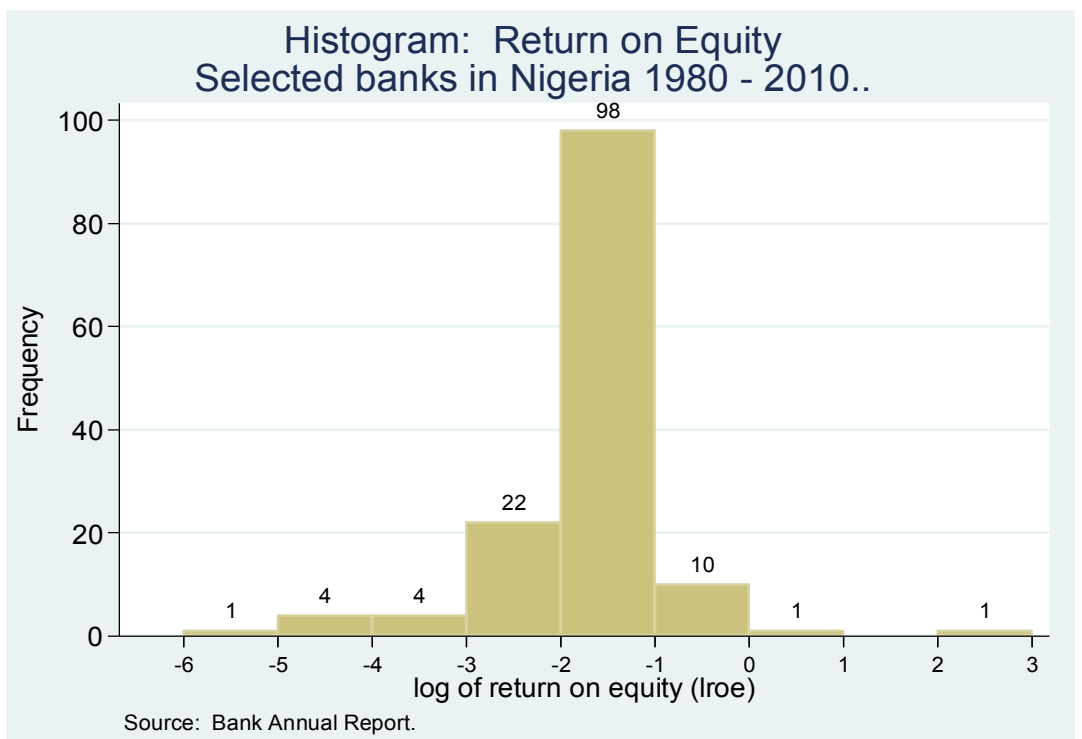

Figure 2. The distribution of return on equity for selected banks in Nigeria 1980-2010

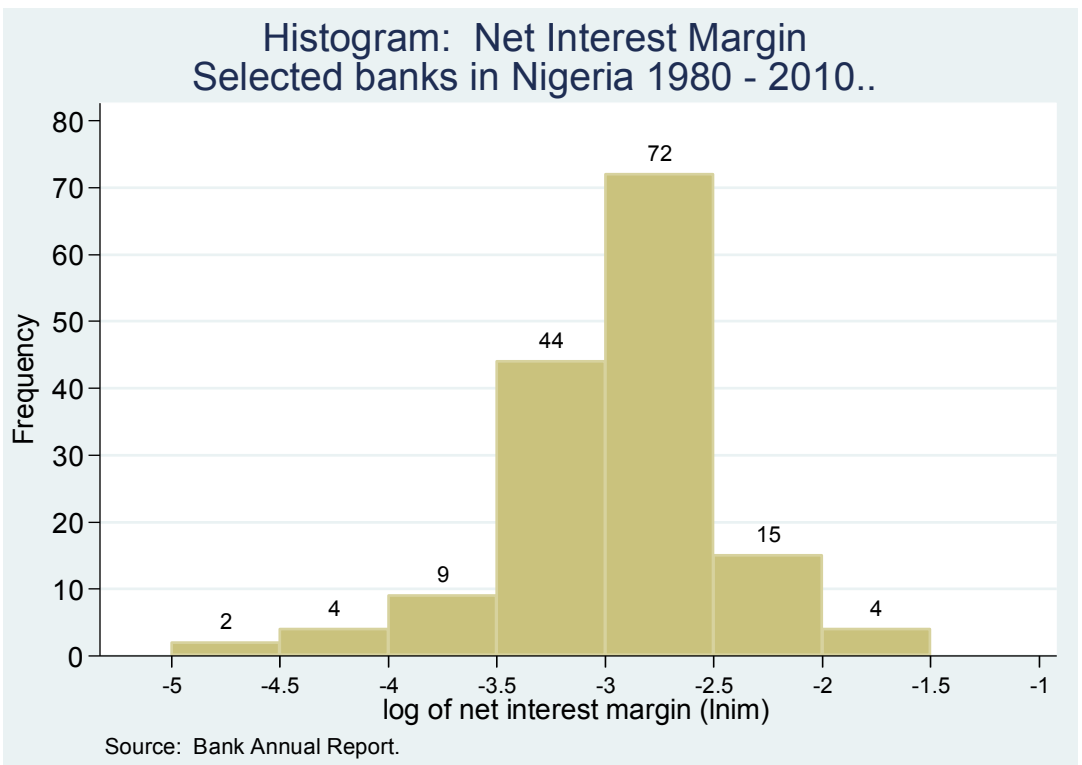

Figure 3. The distribution of net interest margin of banks in Nigeria 1980-2010

The estimation technique follows a panel regression, which provides the advantage of studying a cross section of the banking firms while observing the heterogeneity in the individual firms. Under panel data analysis the fixed and random effects methods of estimation have been applied consecutively. The Hausman specification test (see appendix) is used to ascertain which of the models is most appropriate. The fixed effects within estimator otherwise called entity demeaning model and the generalized least squares method for the random effects model is applied. The fixed effects model is often controlled for time invariant characteristics that will arise between firms in the model in order to reduce omitted variable bias. The random effects model therefore assumes that the differences across the banking firms in this estimation does not follow any predictive pattern and are uncorrelated with the explanatory variables, hence time invariant variables can be included in the model unlike the fixed effects model.

The base model for this study is as stipulated in equation (1) of the model specification. The profit function is broken down into three basic dependent variables namely return on asset, return on equity and net interest margin. The explanatory variables are the same for the three models of estimation.

In the fixed effects "within" entity model shown in Table 3, there is evidence of multicollinearity which informs why the coefficients for market concentration variable $l$ hhi and the macroeconomic variable lexr were dropped 
from the estimation output. However, to correct for this anomaly, a parsimonious model which excludes the macroeconomic variable linf, is applied in subsequent analysis to eliminate the bias. The results are presented in Tables 5 and 6 for the fixed and random effects estimation of a parsimonious model respectively.

Table 4 reports the results of random effects generalized least squares estimation. The Hausman specification test reported in the appendix shows that the random effects model in Table 4 is a better estimate of the explanatory variable for return on asset lroa and return on equity lroe as measures of profitability compared to the fixed effects within estimation result in Table 3. Nevertheless, for the net interest margin lnim, the fixed effects model in Table 3 is found to be a better estimator. The presence of multicollinear variables leads to a further step in the analysis to drop inflation rate as a variable, which most likely introduced the bias.

The result of a parsimonious model that excludes inflation rate with a view to eliminating the collinear effect is presented in Tables 5 and 6 for the fixed and random effects model respectively. The relevant Hausman specification test was conducted to reveal that the random effects model is the most appropriate method of estimation for all the three profitability measures used in this study. Result of the Hausman specification test is presented in the appendix. As a result, the discussion will focus on the result presented in Table 6 for the random effects estimation of a parsimonious model which excludes inflation rate as an explanatory variable.

Table 3. Regression results for fixed effects model

\begin{tabular}{|c|c|c|c|}
\hline & log of return on asset & $\begin{array}{c}(2) \\
\log \text { of return on equity }\end{array}$ & $\begin{array}{c}\text { (3) } \\
\log \text { of net interest margin }\end{array}$ \\
\hline \multirow[t]{2}{*}{ Opportunity Cost of holding reserves with Central Bank } & $-0.220^{* * *}$ & $-0.197^{* *}$ & -0.0682 \\
\hline & $(0.0730)$ & $(0.0970)$ & $(0.0451)$ \\
\hline \multirow[t]{2}{*}{ Ratio of Demand Deposit to Total deposit } & -0.111 & -0.115 & 0.0246 \\
\hline & $(0.317)$ & $(0.422)$ & $(0.189)$ \\
\hline \multirow[t]{2}{*}{ Ratio of Non-Performing Loans to Total Loans } & $-1.530^{* * *}$ & -1.099 & -0.357 \\
\hline & $(0.503)$ & $(0.669)$ & $(0.285)$ \\
\hline \multirow[t]{2}{*}{ Ratio of Non-Interest Income to Operating Profit } & $0.00470^{*}$ & 0.00459 & 0.000958 \\
\hline & $(0.00242)$ & $(0.00321)$ & $(0.00153)$ \\
\hline \multirow[t]{2}{*}{ Ratio of Operating Expenses to Total Assets } & $11.34^{* * *}$ & $12.37^{* * *}$ & $9.611^{* * *}$ \\
\hline & $(3.273)$ & $(4.349)$ & $(1.895)$ \\
\hline \multirow[t]{2}{*}{ Ratio of Total Loans to Total Assets } & -1.272 & $-2.015^{*}$ & -0.539 \\
\hline & $(0.867)$ & $(1.152)$ & $(0.438)$ \\
\hline \multirow[t]{2}{*}{ Ratio of Total Deposit to Total Loans } & $-0.290^{* *}$ & -0.141 & $-0.124^{*}$ \\
\hline & $(0.113)$ & $(0.150)$ & $(0.0640)$ \\
\hline \multirow[t]{2}{*}{ log of Hirschman-Herfindahl index } & 0 & 0 & 0 \\
\hline & (.) & (.) & (.) \\
\hline \multirow[t]{2}{*}{ log of exchange rate of Nigerian naira to US dollar } & 0 & 0 & 0 \\
\hline & (.) & (.) & (.) \\
\hline \multirow[t]{2}{*}{$\log$ of inflation rate } & -0.0902 & -0.0975 & 0.0446 \\
\hline & $(0.275)$ & $(0.365)$ & $(0.174)$ \\
\hline \multirow[t]{2}{*}{ Constant } & $-2.877^{* * *}$ & -0.401 & $-2.957^{* * *}$ \\
\hline & $(0.974)$ & $(1.295)$ & $(0.567)$ \\
\hline Observations & 141 & 141 & 150 \\
\hline$R^{2}$ & 0.303 & 0.145 & 0.265 \\
\hline Adjusted $R^{2}$ & 0.052 & -0.162 & 0.023 \\
\hline $\mathrm{F}$ & 5.585 & 2.189 & 5.054 \\
\hline Prob $>$ F & 0.000 & 0.034 & 0.000 \\
\hline Rmse & 0.572 & 0.761 & 0.363 \\
\hline
\end{tabular}

Note. 1). Robust standard errors are displayed in parenthesis. 2). Omitted coefficients are multicollinear.

Significance levels: $* \mathrm{p}<0.10 ; * * \mathrm{p}<0.05 ; * * * \mathrm{p}<0.01$.

Source: Bank Annual Report and CBN Bulletin for various years (1980-2010).

A further diagnostic test which eliminates the consideration of an ordinary least squares (OLS) as a method of estimation in this study is introduced; the Breusch-Pagan Lagrange Multiplier test (see appendix) decides 
whether a random effect regression is needed as opposed to a simple ordinary least squares. In this case, it is found that the random effects model is the most appropriate in all cases.

Table 4. Regression results for random effects model

\begin{tabular}{|c|c|c|c|}
\hline & $\begin{array}{c}\text { (1) } \\
\log \text { of return on asset }\end{array}$ & $\begin{array}{c}\text { (2) } \\
\log \text { of return on equity }\end{array}$ & $\begin{array}{c}(3) \\
\log \text { of net interest margin }\end{array}$ \\
\hline \multirow[t]{2}{*}{ Opportunity Cost of holding reserves with Central Bank } & $-0.174^{* * *}$ & $-0.153^{*}$ & 0.0432 \\
\hline & $(0.0658)$ & $(0.0837)$ & $(0.0321)$ \\
\hline \multirow[t]{2}{*}{ Ratio of Demand Deposit to Total deposit } & -0.111 & -0.0727 & -0.0943 \\
\hline & $(0.307)$ & $(0.398)$ & $(0.176)$ \\
\hline \multirow[t]{2}{*}{ Ratio of Non-Performing Loans to Total Loans } & $-1.342^{* * *}$ & -0.836 & -0.0515 \\
\hline & $(0.479)$ & $(0.620)$ & $(0.255)$ \\
\hline \multirow[t]{2}{*}{ Ratio of Non-Interest Income to Operating Profit } & $0.00461^{*}$ & 0.00439 & 0.00143 \\
\hline & $(0.00235)$ & $(0.00305)$ & $(0.00140)$ \\
\hline \multirow[t]{2}{*}{ Ratio of Operating Expenses to Total Assets } & $9.907^{* * *}$ & $11.29^{* * *}$ & $8.854^{* * *}$ \\
\hline & (3.121) & $(4.024)$ & (1.636) \\
\hline \multirow[t]{2}{*}{ Ratio of Total Loans to Total Assets } & $-1.496^{*}$ & $-2.151^{* *}$ & $-0.882^{* *}$ \\
\hline & $(0.844)$ & $(1.096)$ & $(0.398)$ \\
\hline \multirow[t]{2}{*}{ Ratio of Total Deposit to Total Loans } & $-0.304^{* * *}$ & -0.151 & $-0.139^{* *}$ \\
\hline & $(0.110)$ & $(0.143)$ & $(0.0602)$ \\
\hline \multirow[t]{2}{*}{$\log$ of Hirschman-Herfindahl index } & $-3.211^{*}$ & $-4.043^{* *}$ & $-1.445^{* * *}$ \\
\hline & $(1.771)$ & $(2.048)$ & $(0.533)$ \\
\hline \multirow[t]{2}{*}{ log of exchange rate of Nigerian naira to US dollar } & 0.0680 & $-0.151^{*}$ & 0.0361 \\
\hline & $(0.0669)$ & $(0.0777)$ & $(0.0231)$ \\
\hline \multirow[t]{2}{*}{$\log$ of inflation rate } & 0.0791 & 0.0789 & -0.0222 \\
\hline & $(0.138)$ & $(0.161)$ & $(0.0434)$ \\
\hline \multirow[t]{2}{*}{ Constant } & 21.88 & $31.41^{*}$ & $8.549^{* *}$ \\
\hline & $(13.98)$ & $(16.14)$ & $(4.168)$ \\
\hline Observations & 141 & 141 & 150 \\
\hline$R^{2}$ & 0.296 & 0.14 & 0.79 \\
\hline Adjusted $R^{2}$ & 0.225 & 0.15 & 0.48 \\
\hline F(Wald Chi^2(10)) & 46.87 & 24.27 & 131.67 \\
\hline Prob $>\mathrm{Chi}^{\wedge} 2$ & 0.000 & 0.007 & 0.000 \\
\hline Rmse & 0.568 & 0.742 & 0.369 \\
\hline
\end{tabular}

Note. 1). Robust standard errors are displayed in parenthesis. 2). No omitted coefficient for random effects.

Significance levels: * $\mathrm{p}<0.10 ; * * \mathrm{p}<0.05 ; * * * \mathrm{p}<0.01$.

Source: Bank Annual Report and CBN Bulletin for various years (1980-2010).

Table 5. Regression result for fixed effects parsimonious model

\begin{tabular}{|c|c|c|c|}
\hline & $(1)$ & (2) & (3) \\
\hline \multirow{2}{*}{ Opportunity Cost of holding reserves with Central Bank } & log of return on asset & log of return on equity & log of net interest margin \\
\hline & $\begin{array}{l}-0.220 \\
(0.0724)\end{array}$ & $\begin{array}{l}-0.202 \\
(0.0959)\end{array}$ & $\begin{array}{l}-0.0580 \\
(0.0453)\end{array}$ \\
\hline \multirow[t]{2}{*}{ Ratio of Demand Deposit to Total deposit } & -0.121 & -0.121 & 0.0257 \\
\hline & $(0.317)$ & $(0.420)$ & $(0.191)$ \\
\hline \multirow[t]{2}{*}{ Ratio of Non-Performing Loans to Total Loans } & $-1.571^{* * *}$ & $-1.127^{*}$ & -0.323 \\
\hline & $(0.501)$ & $(0.663)$ & $(0.288)$ \\
\hline \multirow[t]{2}{*}{ Ratio of Non-Interest Income to Operating Profit } & $0.00479^{*}$ & 0.00465 & 0.000866 \\
\hline & $(0.00241)$ & $(0.00320)$ & $(0.00154)$ \\
\hline \multirow[t]{2}{*}{ Ratio of Operating Expenses to Total Assets } & $11.20^{* * *}$ & $12.28^{* * *}$ & $9.814^{* * *}$ \\
\hline & $(3.267)$ & $(4.328)$ & $(1.915)$ \\
\hline \multirow[t]{2}{*}{ Ratio of Total Loans to Total Assets } & -1.194 & $-1.961^{*}$ & $-0.735^{*}$ \\
\hline & $(0.862)$ & $(1.142)$ & $(0.431)$ \\
\hline
\end{tabular}




\begin{tabular}{lccc}
\hline Ratio of Total Deposit to Total Loans & $-0.283^{* *}$ & -0.137 & $-0.139^{* *}$ \\
& $(0.113)$ & $(0.149)$ & $(0.0643)$ \\
log of Hirschman-Herfindahl index & $-7.363^{* * *}$ & $-8.041^{* * *}$ & $-2.740^{* * *}$ \\
& $(1.767)$ & $(2.341)$ & $(0.925)$ \\
log of exchange rate of Nigerian naira to US dollar & 0.00565 & $-0.205^{* *}$ & 0.0262 \\
& $(0.0758)$ & $(0.100)$ & $(0.0464)$ \\
Constant & $54.98^{* * *}$ & $63.34^{* * *}$ & $18.81^{* *}$ \\
& $(13.83)$ & $(18.32$ & $(7.218)$ \\
Observations & 141 & 141 & 0.346 \\
$R^{2}$ & 0.390 & 0.280 & 0.138 \\
Adjusted $R^{2}$ & 0.178 & 0.031 & 6.644 \\
F & 7.380 & 4.493 & 0.367 \\
Rmse & 0.572 & 0.758 & \\
\hline
\end{tabular}

Note. 1). Robust standard errors are displayed in parenthesis.

Significance levels: $* \mathrm{p}<0.10 ; * * \mathrm{p}<0.05 ; * * * \mathrm{p}<0.01$.

Source: Bank Annual Report and CBN Bulletin for various years (1980-2010).

In all the regression estimations presented in this study there is an assumption of the presence of heteroskedasticity standard errors. Nonetheless, a test of heteroskedasticity (see appendix) is presented in the appendix and the conclusion is that there is the presence of heteroskedascity consistent standard errors.

Table 6. Regression result for random effects parsimonious model

\begin{tabular}{lccc}
\hline & $(1)$ & $(2)$ & $(3)$ \\
& $\log$ of return on asset & log of return on equity & $\log$ of net interest margin \\
\hline Opportunity Cost of holding reserves with Central Bank & $-0.133^{* * *}$ & -0.130 & 0.0397 \\
& $(0.0627)$ & $(0.0792)$ & $(0.0313)$ \\
Ratio of Demand Deposit to Total deposit & -0.124 & -0.0644 & $(0.0884$ \\
Ratio of Non-Performing Loans to Total Loans & $(0.317)$ & $(0.402)$ & -0.0666 \\
Ratio of Non-Interest Income to Operating Profit & $-1.269^{* * *}$ & -0.758 & $(0.252)$ \\
& $(0.489)$ & $(0.620)$ & 0.00139 \\
Ratio of Operating Expenses to Total Assets & $0.00459^{*}$ & 0.00436 & $(0.00139)$ \\
Ratio of Total Loans to Total Assets & $(0.00243)$ & $(0.00308)$ & $8.842^{* * *}$ \\
Ratio of Total Deposit to Total Loans & $9.319^{* * *}$ & $11.40^{* * *}$ & $(1.631)$ \\
log of Hirschman-Herfindahl index & $(3.176)$ & $(4.023)$ & $-0.842^{* *}$ \\
& $-1.537^{*}$ & $-2.095^{*}$ & $(0.389)$ \\
log of exchange rate of Nigerian naira to US dollar & $(0.871)$ & $(1.105)$ & $-0.135^{* *}$ \\
Constant & $-0.313^{* * *}$ & -0.153 & $(0.0597)$ \\
Observations & $(0.114)$ & $(0.144)$ & $-1.445^{* * *}$ \\
$R^{2}$ & $-3.468^{* * *}$ & $-4.410^{* * *}$ & $(0.531)$ \\
Adjusted $R^{2}$ & $(1.267)$ & $(1.595)$ & $0.0380^{*}$ \\
F & 0.0612 & $-0.159^{* *}$ & $(0.0227)$ \\
\hline
\end{tabular}

Note. 1). Robust standard errors are displayed in parenthesis.

Significance levels: * $\mathrm{p}<0.10 ; * * \mathrm{p}<0.05 ; * * * \mathrm{p}<0.01$.

Source: Bank Annual Report and CBN Bulletin for various years (1980-2010). 


\subsection{Discussion of Results}

The entire discussion of the empirical analysis for this study will come from the random effects parsimonious model in Table 6. From column 1, the estimation results for return on asset as dependent variable show that opportunity cost of holding reserves with the central bank (OPP) is significant and follows apriori expectation. A negative relationship indicates that as banks hold more reserves the level of profitability declines. Reserve holding in this case is seen as a tax on the banking system. The coefficient shows that holding every other variable constant, for every one unit change in reserve requirement, the return on asset decreases by $13.3 \%$. This figure seems large but the interesting thing here is the relationship and not the size of the coefficient. Because of data inconsistency most of the parameter estimates may be outrageous but the important factor remains the observed relationship between the variables.

Another significant variable to return on asset as an estimate of profitability in this study is the ratio of non-performing loans to total loans (NPL), which exhibits a negative relationship and the implication is that as loan default increases bank profits decreases. This result is consistent with the finding in Athanasoglou, et al. (2006) for the Greek banking industry, but contradicts the result in Goddard (2004) for European banks.

The ratio of non-interest income to operating profit (NOP) is also significant in the estimation and follows a positive relationship, which indicates that holding every other variable constant, a unit change in the ratio of non-interest income to operating profit will result to an increase in profitability by $0.459 \%$. The magnitude of change in this case is reasonable and accounts for the contribution of non-interest income such as fees and commission to bank profit.

The ratio of operating expenses to total assets (OEA) is significant to return on assets with a positive relationship. The understanding here is that most of the expenses incurred at the bank level are utilized for improvement on the services of the bank which in turn earns profit. The ratio of total loans to total assets (TLA) is another significant variable with a negative relationship to return on asset as a measure of profitability.

The ratio of demand deposit to total loans (DTL) which is a measure of credit risk is significant to return on assets. The negative relationship implies that as credit risk is increasing profitability is decreasing. This finding follows the result in Kumbakhar et al. (2001) and Zhao and Murinde (2011) for the Spanish and Nigerian banking systems respectively.

The market power variable (lhhi) is a measure of banking industry concentration in this study and is significant to estimating the changes in return on assets. The relationship is negative which signifies that as bank concentration is increasing, profitability is decreasing. This result contradicts the finding in Flamini et al. (2009) for the banking system in sub-Saharan Africa, perhaps because of their choice of overhead costs as a proxy for market concentration. However, there is no evidence of the structure-conduct-performance hypothesis in the banking system but the result is consistent with a non-collusive behavior of firms in the industry. The underlining reasoning here is that banks in Nigeria do not reap oligopolistic profits due to collusive behavior.

The macroeconomic variable exchange rate is not significant in determining changes in return on assets as a measure of profitability. Inflation rate was dropped from the model because of the collinearity with exchange rate. The high correlation between macroeconomic variables must have arisen from the fact that most of the fluctuations in price level in the macro economy result from currency devaluation implemented over the period. Exchange rate devaluation feeds into the inflation cycle in the macro economy and hence accounts for a high degree of changes in the price level, which is captured as inflation rate.

The results of estimation in Table 6 columns 2 and 3 estimates the relationship between the explanatory variables and return on equity and net interest margin as measures of profitability respectively. The results indicate that the ratio of operating expense to total assets (OEA) is significant with a positive relationship in determining changes in return on equity and net interest margin. Similarly, the ratio of total loans to total assets (TLA) is also significant with a negative relationship, but the ratio of total deposit to total loans is not significant for return on equity, but significant for net interest margin with a positive relationship.

Market concentration variable is significant for all measures of profitability with the same negative sign. Macroeconomic variable is significant to return on equity and net interest margin, but with different signs. The negative relationship between exchange rate and return on equity implies that the devaluation of exchange rate accounts for a direct positive change in bank profits. The argument in this instance is that returns to the banking system come through equity investments in currency market transactions. On the other hand, the positive but significant relationship between exchange rate and net interest margin indicates that interest earning transactions were susceptible to changes in the currency exchange fluctuations at least in the positive sense. 


\section{Conclusion}

From the foregoing analysis, it is obvious that bank profit is largely determined by bank specific variables. This finding proclaims that internal organization and managerial effectiveness are important factors in the profitability of banks. As a matter of policy, monetary authorities can therefore use prudential guidelines to effectively manage the activities of the banking industry. Bank management on the other hand can effectively pursue policies that will enhance their balance sheet positions without regard to external influences.

Market concentration is also a major determinant of bank profitability. Although there is no notable evidence for the structure-conduct-performance hypothesis in the Nigerian banking industry, the finding in this study shows that market concentration does not proportionately change profitability. This implies that there is no collusive behavior amongst firms to reap excessive profit in an oligopolistic market framework in the industry. Firms are absolutely independent in their decision making. No individual firm has an over bearing influence on the market.

Macroeconomic variables intended for analysis in this study did not pass the multicollinearity test. Inflation rate and exchange rate were the most feasible macroeconomic variables that demonstrate tremendous impact on bank profitability according to the literature. In this study both variables were collinear, which to a large to extent is as a result of the macroeconomic policies adopted in Nigeria since the late 1980's. The exchange rate of the naira was allowed to float and it suffered a series of devaluation over the period. A very high percentage of the fluctuations in the price level could be attributed to currency devaluation. This is evidenced by the high correlation between exchange rate and inflation.

Exchange rate is a determinant of bank profitability when return on equity and net interest margin are used as measures of bank profitability. The insignificance of exchange rate to return on asset is perhaps attributed to the fact that a very large percentage of bank assets are fixed or off balance sheet items. The variability of the asset portfolio of banking firms is not largely responsive to the variations in exchange rate.

A major challenge that emanates from the findings of this study is the inability of banking firms to maintain a reasonable level of liquidity provisions. The liquidity position of a bank determines its level of shock absorption in the case of any shortfall. The impact of deposit mix on profitability is captured by the ratio of demand deposits to total deposits of which a very high proportion increases the performance of the banking firm. In this study, this ratio is not significant to determining profitability. Bank management should be encouraged to pursue policies that effectively enhance liquidity provisions but not at the expense of profitability.

\section{References}

Abreu, M., \& Mendes, V. (2002). Commercial bank interest margins and profitability: Evidence from E.U countries. Porto Working paper series.

Aburime, T., \& Uche, C. U. (2008). Impact of share capitalization on bank profitability in Nigeria. European Journal of Scientific Research, 19(3), 438-452.

Albertazzi, U., \& Gambacorta, L. (2006). Bank Profitability and the Business Cycle. Bank of Italy Economic Research Paper No. 601.

Al-Hashimi, A. (2007). Determinants of Bank Spreads in Sub-Saharan Africa. IMF Draft. Working Paper, 05/06.

Angbazo, L. (1997). Commercial Banks, Net Interest Margins, Default Risk, Interest Rate Risk and Off-Balance Sheet Banking. Journal of Banking and Finance, 21, 55-87. http://dx.doi.org/10.1016/S0378-4266(96)00025-8

Arteta, C., \& Barry, E. (2002). Banking Crises in Emerging Markets: Presumptions and Evidence. In M. Blejer $\&$ M. Skreb (Eds.), Financial Policies in Emerging Markets. Cambridge, Massachussetts: MIT Press.

Athanasoglou, P. P., Delis, M. D., \& Staikoras, C. C. (2006). Determinants of Bank Profitability in the South Eastern European Region. Bank of Greece, Working Paper No. 47, September 2003.

Athanasoglou, P. P., Georgiou, E. A., \& Staikoras, C. C. (2008). Assessing Output and Productivity Growth in the Banking Industry. Bank of Greece Working Paper No. 92, November.

Barajas, A., Steiner, R., \& Salazar, N. (1999). Interest Spreads in Columbia, 1974-1996. IMF Staff Papers, $46(2)$.

Beck, T. (2008). Bank competition and financial stability: friends or foes? World Bank policy research working paper number 4656.

Beck, T., Robert, C., \& Afeikhena, J. (2005). Bank Privatization and Performance: Empirical Evidence from Nigeria. Journal of Banking and Finance, 29, 2355-2379. http://dx.doi.org/10.1016/j.jbankfin.2005.03.018 
Berger, A. (1995a). The Relationship between Capital and Earnings in Banking. Journal of Money, Credit and Banking, 27, 432-456. http://dx.doi.org/10.2307/2077877

Berger, A. (1995b). The Profit-Structure relationship in banking: Tests of market power and efficient structure hypothesis. Journal of Money, Credit and Banking, 27, 404-431. http://dx.doi.org/10.2307/2077876

Berger, A. N., Hanweck, G., \& Humphrey, D. (1987). Competitive viability in banking: Scale, scope and product mix economies. Journal of Monetary Economics, 20, 501-520. http://dx.doi.org/10.1016/0304-3932(87)90039-0

Bikker, J. A., \& Bos, J. W. B. (2008). Bank Performance: A theoretical and empirical framework for the analysis for profitability, competition and efficiency. Routledge: New York.

Bourke, P. (1989). Concentration and other determinants of bank profitability in Europe, North America and Australia. Journal of Banking and Finance, 13, 65-79. http://dx.doi.org/10.1016/0378-4266(89)90020-4

Brissimis, S. N., Delis, M. D., \& Papanikolaou, N. I. (2008). Exploring the Nexus between Banking Sector Reform and Performance: Evidence from Newly Acceded EU Countries. Journal of Banking and Finance, 32, 2674-2683. http://dx.doi.org/10.1016/j.jbankfin.2008.07.002

Chen, C. (2009). Bank Efficiency in Sub-Saharan African Middle-Income Countries. International Monetary Fund.

Chirwa, W. E. (2003). Determinants of Commercial Banks' Profitability in Malawi: A Cointegration Approach. Applied Financial Economics, 13(8), 565-571. http://dx.doi.org/10.1080/0960310022000020933

Chirwa, W. E., \& Mlachila, M. (2004). Financial Reforms and Interest Rate Spreads in the Commercial Banking System in Malawi. IMF Staff Papers, 51(1), 96-122.

Claessens, S., \& Laeven, L. (2004). What drives bank competition? Some International Evidence. Journal of Money, Credit and Banking, 36, 563-583. http://dx.doi.org/10.1353/mcb.2004.0044

Demirgüç-Kunt, A., \& Harry, H. (1999). Determinants of Commercial Bank Interest Margins and Profitability: Some International Evidence. The World Bank Economic Review, 13(2), 379-408. http://dx.doi.org/10.1093/wber/13.2.379

Domaç, I., \& Maria, S. M. P. (2003). Banking Crises and Exchange Rate Regimes: Is there a link? Journal of International Economics, 61(1), 41-72. http://dx.doi.org/10.1016/S0022-1996(02)00081-8

Duca, J., \& McLaughlin, M. (1990). Developments affecting the profitability of commercial banks. Federal Reserve Bulletin.

Egesa, K. A. (2010). Financial Sector Liberalization and Productivity Change in Uganda's Commercial Banking Sector. AERC Research Paper 202, African Economic Research Consortium Nairobi Kenya 2010.

Flamini, V., Calvin, M., \& Liliana, S. (2009). The Determinants of Commercial Bank Profitability in Sub-Saharan Africa. International Monetary Fund.

Fries, S., \& Taci, A. (2005). Cost efficiency of banks in transition: Evidence from 289 banks in 15 post-communist countries. Journal of Banking and Finance, 29, 55-81. http://dx.doi.org/10.1016/j.jbankfin.2004.06.016

Fu, X., \& Shelagh, H. (2009). The Effects of Reform on China's Bank Structure and Performance. Journal of Banking \& Finance, 33, 39-52. http://dx.doi.org/10.1016/j.jbankfin.2006.11.023

Gelos, G. (2006). Banking Spreads in Latin America. IMF Working Paper 06/44. http://dx.doi.org/10.5089/9781451863048.001

Goddard, J., Molyneux, P., \& Wilson, J. (2004). Dynamics of Growth and Profitability in Banking. Journal of Money, Credit and Banking, 36, 1069-1090. http://dx.doi.org/10.1353/mcb.2005.0015

Harry, H. (2001). Financial Structure and Bank Profitability. World Bank Mimeo.

Ho, T. S. Y., \& Saunders, A. (1981). The Determinants of Bank Interest Margins: Theory and Empirical Evidence. Journal of Financial and Quantitative Analysis, 16(04), 581-600. http://dx.doi.org/10.2307/2330377

Kosmidou, K., Pasiouras, F., Doumpos, M., \& Zopounidis, C. (2006). Assessing Performance Factors in the UK Banking Sector: A Multicriteria Approach. Central European J. Operations Res., 14(1), $25-44$. http://dx.doi.org/10.1007/s10100-006-0158-5

Kumbhakar, S. C., Lozzano-Vivas, A., Lovell, C. A. K., \& Hasan, I. (2001). The Effects of Deregulation on the 
Performance of Financial Institutions: The case of Spanish Savings Banks. Journal of Money, Credit and Banking, 33, 101-120. http://dx.doi.org/10.2307/2673874

Mamatzakis, E. C., \& Remoundos, P. C. (2003). Determinants of Greek Commercial Banks Profitability (19892000). Spoudai, 53(1).

Maudos, J., \& Fernandez, D. G. J. (2004). Factors Explaining the Interest Margin in the Banking Sectors of European Union. Journal of Banking and Finance, 28, 2259-2281. http://dx.doi.org/10.1016/j.jbankfin.2003.09.004

Micco, A., Panizza, U., \& Yañez, M. (2007). Bank ownership and performance. Does politics matter? Journal of Banking and Finance, 31, 219-241. http://dx.doi.org/10.1016/j.jbankfin.2006.02.007

Molyneux, P. (1993). Market Structure and Profitability in European Banking. Institute of European Finance, University College of North Wales, Research Paper 9.

Molyneux, P., \& Thornton, J. (1992). Determinants of European banks profitability: A note. Journal of Banking and Finance, 16, 1176-1178. http://dx.doi.org/10.1016/0378-4266(92)90065-8

Naceur, S. B. (2003). The Determinants of the Tunisian Banking Industry Profitability: Panel Evidence. Universite Libre de Tunis. Working Papers.

Naceur, S. B., \& Goaied, M. (2001). The determinants of the Tunisian deposit banks' performance. Applied Financial Economics, 11, 317-319. http://dx.doi.org/10.1080/096031001300138717

Neely, M., \& Wheelock, D. (1997). Why does Bank Performance vary across States? Federal Reserve Bank of St. Louis Review, 27-38.

Okonjo-Iweala, N. (2012). Reforming the Unreformable: Lessons from Nigeria. Cambridge Massachusetts, MIT Press.

Saunders, A., \& Allen, L. (2004). Incorporating Systemic Influences into Risk Measurements: A Survey of the Literature. Journal of Financial Services Research, 26(2), 161-191. http://dx.doi.org/10.1023/B:FINA.0000037545.38154.8a

Saunders, A., \& Schumacher, L. (2000). The Determinants of Bank Interest Rate Margins: An International Study. Journal of International Money and Finance, 19, 813-832. http://dx.doi.org/10.1016/S0261-5606(00)00033-4

Soedarmono, W. (2010). Bank competition, institution and economic development: Evidence from Asia during 1999-2007. Economics Bulletin, 30(3), 2119-2133.

Staikouras, C. K., \& Wood, G. E. (2004). The Determinants of European Bank Profitability. International Business \& Economics Research Journal, 3(6).

Zhao, T., \& Murinde, V. (2011). Bank Deregulation and Performance in Nigeria. African Development Review, 23(1), 30-43. http://dx.doi.org/10.1111/j.1467-8268.2010.00270.x

\section{Appendix A}

\section{Hausman Specification Tests for Fixed or Random Effects Models}

Model 1: log of return on assets (lroa) as dependent variable, the random effects model is a better fit for with and without inflation rate $(\operatorname{linf})$ as an explanatory variable.

Test: Ho: difference in coefficients not systematic

$$
\begin{array}{rlc} 
& \text { With linf } & \text { without linf } \\
\text { chi2 }(8)= & 6.12 & 11.36 \\
\text { Prob }>\text { chi } 2= & 0.6335 & 0.252
\end{array}
$$

Model 2: $\log$ of return on equity (lroe) as dependent variable, the random effects model is a good fit with and without inflation rate $(\operatorname{linf})$ as an explanatory variable.

Test: Ho: difference in coefficients not systematic 


$$
\begin{array}{ccc}
\text { With linf } & \text { without linf } \\
\text { chi2 }(8)= & 2.29 & 12.96 \\
\text { Prob }>\text { chi2 }= & 0.9707 & 0.165
\end{array}
$$

Model 3: log of net interest margin (lnim) as dependent variable, the fixed effects model is a good fit with inflation rate as an explanatory variable, but the random effects is better estimate without inflation rate in the model as an explanatory variable.

Test: Ho: difference in coefficients not systematic

$$
\begin{array}{rcc}
\text { With linf } & \text { without linf } \\
\text { chi2 }(8)= & 16.55 & 13.51 \\
\text { Prob }>\text { chi2 }= & 0.0352 & 0.141
\end{array}
$$

Note: The test statistic is that if Prob $>$ Chi2 is less than 0.05 , we reject the null hypothesis and conclude that the most appropriate is the fixed effects model, otherwise the random effect becomes the model of best fit.

\section{Appendix B}

\section{Testing for Random Effects-Breusch-Pagan Lagrange Multiplier (LM) Test}

(i) Estimated results for model 1, using log of return on assets (lroa) as dependent variable with and without log of inflation rate (linf) as an explanatory variable:

\begin{tabular}{ccccc}
\hline & Variance & \multicolumn{3}{c}{ Standard deviation = Sqrt(Variance) } \\
\hline & with linf & without linf & with linf & without linf \\
lroa & 0.6028 & 0.6028 & 0.7764 & 0.7764 \\
$\mathrm{e}$ & 0.3277 & 0.3271 & 0.5724 & 0.5719 \\
$\mathrm{u}$ & 0.3292 & 0.1127 & 0.5738 & 0.3357 \\
\hline
\end{tabular}

$$
\begin{array}{rcc}
\text { With linf } & \text { without linf } \\
\text { Test: } \operatorname{Var}(\mathrm{u})= & 0 & 0 \\
\text { chibar2 }(01)= & 3.82 & 21.89 \\
\text { Prob }>\text { chibar2 }= & 0.0253 & 0.0000
\end{array}
$$

(ii) Estimated results for model 2, using $\log$ of return on equity (lroe) as dependent variable with and without inflation rate (linf) as an explanatory variable:

\begin{tabular}{ccccc}
\hline & Variance & \multicolumn{3}{c}{ Standard deviation = Sqrt(Variance) } \\
\hline & With linf & Without linf & With linf & Without linf \\
lroe & 0.8290 & 0.8290 & 0.9105 & 0.9105 \\
$\mathrm{e}$ & 0.5785 & 0.5742 & 0.7606 & 0.7578 \\
$\mathrm{u}$ & 0.3943 & 0.1851 & 0.6280 & 0.4302 \\
\hline
\end{tabular}

$\begin{array}{ccc}\text { With linf } & \text { without li } \\ \text { Test: } \operatorname{Var}(\mathrm{u})= & 0 & 0 \\ \text { chibar2 }(01)= & 2.70 & 9.80 \\ \text { Prob }>\text { chibar } 2= & 0.0501 & 0.0009\end{array}$

There is no need to apply the Breusch-Pagan LM test for model 3, because from the Hausman specification test the fixed effects model is equally plausible for the estimation with linf as an explanatory variable. On the other hand the random effect is a good fit without linf as an explanatory variable.

The null hypothesis for the Breusch-Pagan LM test is that the variance across entities is zero; no significant difference across Panel. This test is to decide between a random effects regression and a simple OLS regression.

Note: In all cases above, the null hypothesis is rejected and we conclude that there is significant difference across banking firms and hence the random effects model is the most appropriate method of estimation. 


\section{Appendix C}

\section{Testing for Heteroskedasticity}

The result of a modified Wald test for groupwise heteroskedasticity in fixed effect regression model is as follows;

$$
\begin{gathered}
\text { H0: } \operatorname{sigma}(i)^{\wedge} 2=\operatorname{sigma}^{\wedge} 2 \text { for all } \mathrm{i} \\
\text { chi } 2(28)=2068.72 \\
\text { Prob }>\text { chi } 2=0.0000
\end{gathered}
$$

The null hypothesis is homoscedasticity or constant variance. In this case, we reject the null hypothesis since Prob $>$ chi2 is less than 0.05 and conclude that there is presence of heteroskedasticity.

\section{Copyrights}

Copyright for this article is retained by the author(s), with first publication rights granted to the journal.

This is an open-access article distributed under the terms and conditions of the Creative Commons Attribution license (http://creativecommons.org/licenses/by/3.0/). 